\title{
Bronchopulmonary moniliasis in the newborn
}

\author{
ALENA LINHARTOVÁ AND W. CHUNG \\ From the Sikl Institute of Pathological Anatomy, Charles University, Plzě̆, and the Department of \\ Pathology, County General Hospital (OUNZ), Karlovy Vary, Czechoslovakia
}

SYNOPSIS Ten instances of bronchopulmonary moniliasis due to $C$. albicans in neonatal infants $\vec{\omega}$ 1 to 11 days of age, are described. The incidence was $1.05 \%$ out of a total of 947 consecutive necropsies on neonates. Diagnosis was established by morphological identification of the fungi? Seven cases were associated with inflammatory exudation. In three cases inflammation was absent? Infection secondary to monilial vaginitis in the mother appears to have been over-emphasized The more common mechanism appears to be aspiration after delivery.

Although moniliasis of the mouth, larynx, oesophagus, and gastrointestinal tract in infants is well known, its occurrence in the lungs is a distinctly rare finding in the immediate neonatal period. The only references we have been able to find are those of Birch-Hirschfeld (1875, cited by Dobias, 1957), Vorreith (1953), and Hottinger (1956) who each reported single cases. The pulmonary lesion was secondary to monilial sepsis and thus differs from the subject of the present study. Nézelof and Sarraut (1957) listed a case of isolated monilial pneumonia that is similar to ours. Ludlam and Henderson (1942) mention the occurrence of pulmonary moniliasis in the neonatal infant, but no details are given. Consequently a report appears warranted of 10 instances of bronchopulmonary moniliasis in neonates due to C. albicans.

\section{MATERIAL AND METHODS}

A neonate for the purpose of this study is defined as a newborn infant up to the age of 10 days. During the period of observation a combined total of 947 neonates was necropsied. Lung tissues for histological study were routinely stained with haematoxylin-eosin, supplemented by Gram and P.A.S. staining, and, in a few instances, by staining with Gomori's hexamethylenetetramine reagent. Bronchial swabs for cultivation were taken in two cases and inoculated on Sabouraud media.

\section{RESULTS}

The age, sex, birth weight and length, therapy, and summary of pathological findings are listed in Table I. Ten instances of bronchopulmonary moniliasis were discovered, representing an incidence of
$1.05 \%$. Two infants, aged 11 days, have also beeri included in the series. The sexes were evenly distric buted. The youngest newborn was 1 day of age? Delivery was by caesarean section in one case (no. 2) $\overrightarrow{\mathrm{c}}$ Deliveries were in all cases performed in a maternit\& ward, and the infants were under institutional care until the time of death. When present, clinical signe pointing to respiratory complication (cyanosis? temperature, and tachypnoea) appeared, on the average, on the sixth day after delivery. Positive cultures of $C$. albicans were not obtained from ant case.

\section{GROSS FINDINGS}

In cases $1,8,9$, and 10 the lungs were not charactero istic in any way but merely showed patchy areas of atelectasis. In the remaining neonates the para vertebral areas exhibited focal or diffuse consolidas tion of varying degree. To the naked eye the lung parenchyma presented numerous dark red areas with small yellow nodules about 2 to $5 \mathrm{~mm}$. in diametes and somewhat soft in consistency. Liquefaction was visible in the centre of some of the nodules. In two instances the overlying pleura was covered with fibrin, and in one the pleural cavity contained te purulent exudate. The large bronchi were generalles normal in appearance. Occasionally they were filled with a viscous liquid, light brown or pale yellow id colour.

\section{HISTOLOGY}

Two distinct groups were noted, one with and the other without an inflammatory reaction. In the former group (cases 1 to 7) large areas of alveoli ang 
TABLE I

SUMMARY OF CLINICAL DATA, THERAPY, AND PATHOLOGICAL FINDINGS

\begin{tabular}{|c|c|c|c|c|c|c|c|c|c|c|}
\hline No. & $\begin{array}{l}\text { Weight } \\
\text { (g.) }\end{array}$ & $\begin{array}{l}\text { Length } \\
(\mathrm{cm} .)\end{array}$ & $\operatorname{Sex}$ & $\begin{array}{l}\text { Age } \\
\text { (days) }\end{array}$ & $\begin{array}{l}\text { First } \\
\text { Clinical } \\
\text { Signs (day } \\
\text { after } \\
\text { delivery) }\end{array}$ & Antibiotics & Localization & Bacteria & Aspiration & Other Pathological Findings \\
\hline 1 & 2,050 & 47 & $\mathbf{F}$ & 4 & - & $\begin{array}{l}\text { Penicillin } \\
\text { Streptomycin }\end{array}$ & Lungs & Gram - bacilli & 一 & $\begin{array}{l}\text { Haematorachis, diffused renal } \\
\text { necrosis }\end{array}$ \\
\hline 2 & 2,600 & 44 & $\mathbf{M}$ & 6 & 2 & $\begin{array}{l}\text { Penicillin } \\
\text { Streptomycin } \\
\text { Aureomycin }\end{array}$ & Lungs & Gram - bacilli & $\begin{array}{l}\text { Milk } \\
\text { Vernix }\end{array}$ & - \\
\hline 3 & 2,600 & 52 & $\mathbf{F}$ & 10 & 5 & $\begin{array}{l}\text { Penicillin } \\
\text { Terramycin }\end{array}$ & $\begin{array}{l}\text { Pharynx } \\
\text { Oesophagus } \\
\text { Lungs }\end{array}$ & Gram + cocci & $\begin{array}{l}\text { Vegetable } \\
\text { particles }\end{array}$ & $\begin{array}{l}\text { Thrombosis of ductus arteriosus, } \\
\text { enterocolitis, otitis media, slight } \\
\text { nephrosis with calcification }\end{array}$ \\
\hline 4 & 2,850 & 50 & $\mathbf{M}$ & 11 & 10 & $\begin{array}{l}\text { Penicillin } \\
\text { Streptomycin } \\
\text { Aureomycin } \\
\text { Terramycin }\end{array}$ & $\begin{array}{l}\text { Oral cavity } \\
\text { Larynx } \\
\text { Pharynx } \\
\text { Lungs Stools }\end{array}$ & Gram + cocsi & $\begin{array}{l}\text { Vegetable } \\
\text { particles }\end{array}$ & Otitis media \\
\hline 5 & 2,350 & 46 & $\mathbf{M}$ & 7 & - & Penicillin & $\begin{array}{l}\text { Oral cavity } \\
\text { Oesophagus } \\
\text { Lungs }\end{array}$ & $\begin{array}{l}\text { Gram }+ \text { cocci } \\
\text { and bacilli }\end{array}$ & Vernix & - \\
\hline 6 & 2,300 & 50 & $\mathbf{F}$ & 11 & 8 & $\begin{array}{l}\text { Penicillin } \\
\text { Streptomycin } \\
\text { Erythromycin } \\
\text { Neomycin }\end{array}$ & Lungs & Gram + cocci & $\begin{array}{l}\text { Vegetable } \\
\text { particles }\end{array}$ & $\begin{array}{l}\text { Ebstein malformation of tri- } \\
\text { cuspidal valve, labile and palatal } \\
\text { cleft }\end{array}$ \\
\hline 7 & 2,650 & 47 & $\mathbf{M}$ & 7 & 6 & $\begin{array}{l}\text { Erythromycin } \\
\text { Penicillin }\end{array}$ & Lungs & Gram + cocci & 一 & 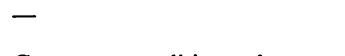 \\
\hline 8 & 1,000 & 27 & $\mathbf{M}$ & 9 & - & $\begin{array}{l}\text { Penicillin } \\
\text { Erythromycin }\end{array}$ & Lungs & Gram + bacilli & Vernix & $\begin{array}{l}\text { Gastroenterocolitis, pulmonary } \\
\text { haemorrhage }\end{array}$ \\
\hline $\begin{array}{r}9 \\
10\end{array}$ & $\begin{array}{l}1,000 \\
2.400\end{array}$ & $\begin{array}{l}34 \\
49\end{array}$ & $\begin{array}{l}\mathbf{F} \\
\mathbf{F}\end{array}$ & $\begin{array}{l}4 \\
1\end{array}$ & - & Penicillin & $\begin{array}{l}\text { Lungs } \\
\text { Lungs }\end{array}$ & Gram-bacilli & Vernix & Pulmonary hyaline membranes \\
\hline
\end{tabular}

bronchi were consolidated by a cellular exudate consisting predominantly of polymorph leucocytes in which masses of blastospores and pseudomycelia of $C$. albicans were present mixed with the inflammatory cells (Figs. 1 and 2). Rarely, the lumina of blood vessels were plugged with organisms. As a rule, pseudomycelia could be seen penetrating the bronchiolar wall into the adjacent lung parenchyma. The epithelial lining of the bronchioles showed occasional focal squamous metaplasia. The inter-alveolar septa were hyperaemic, and, in spots, necrotic or indistinct. Interstitial as well as intra-alveolar haemorrhages were present, particularly in the vicinity of the inflammatory exudate.

Generally, oedema and focally distributed collapse and emphysema were found in one or more areas of all the lung sections. The epithelium of some of the alveoli was hyperplastic. An additional feature in two cases was the finding of a bright yellow material, quite abundant in certain areas, in the bronchi and alveoli. It was identified as bilirubin with Fouchet's reagent (Hall, 1960). In one instance a few scattered giant cells were seen phagocytozing blastospores and, rarely, pseudomycelia (Fig. 3). In two cases the bronchi and bronchioli were filled with quantities of particles, most probably of vegetable origin (Fig. 4), closely associated with the mycotic flora (Fig. 5).

In the second group (cases 8 to 10), in which there was no inflammatory reaction, Candida varied considerably in number. In case 10 they occurred as dis- crete, isolated forms in a few bronchioli. In the other two cases they were present as more abundant growths in the bronchioli as well as in a few alveoli. The lung parenchyma was for the most part atelectatic with foci of intra-alveolar haemorrhages. In case 8 a number of bronchioli contained particles identical to those described above.

In the majority of cases in both groups $C$. albicans was found, mainly in the form of blastospores. The intermingled pseudomycelia when present were distinctive and were easily identified (Fig. 6). Except in cases 1,7 , and 10 , aspirated vernix squames, milk, and vegetable particles were found in one form or another in all the lungs but Candida only in the vegetable particles. Bacteria in varying numbers were identified morphologically in all instances except in case 10.

An incidental finding was the small foci of necrosis and leucocytic infiltration in the renal medulla in case 1. Gram, P.A.S., and polychrome blue staining did not disclose Candida or any other infectious organism.

Candida were seen in cases 3, 4, and 5 in sites other than the lung.

\section{DISCUSSION}

Judging by the bronchial propagation of the fungi, it is clear that the portal of entry in our series of cases was the upper respiratory tract. Hence, moniliasis 


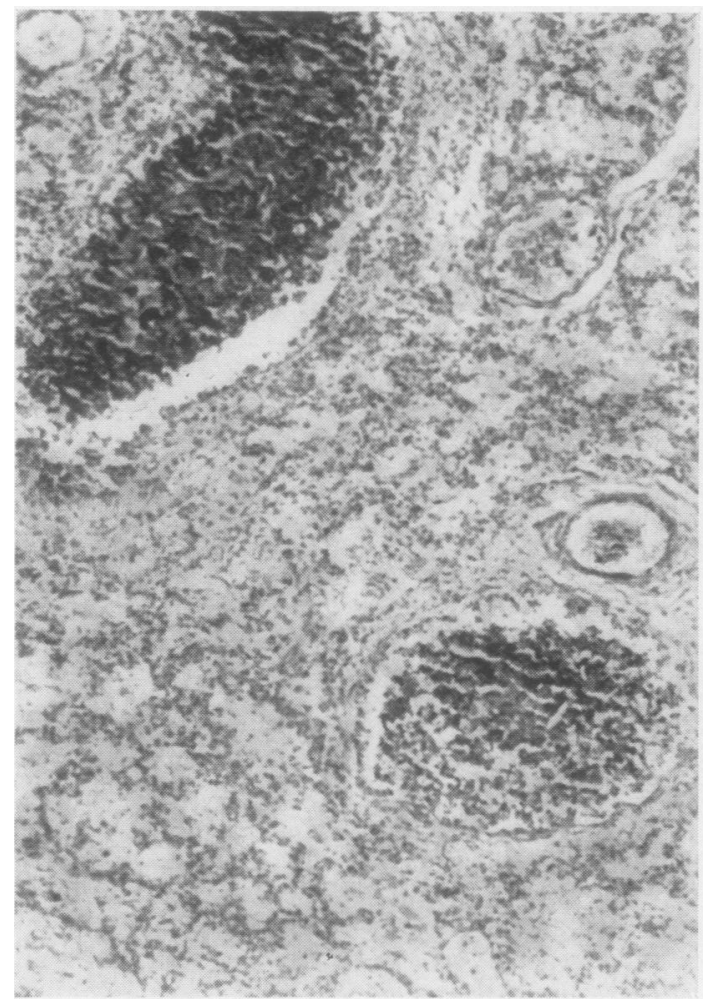

FIG. 1. The bronchi are choked with blastospores of Candida. P.A.S. $\times 64$.

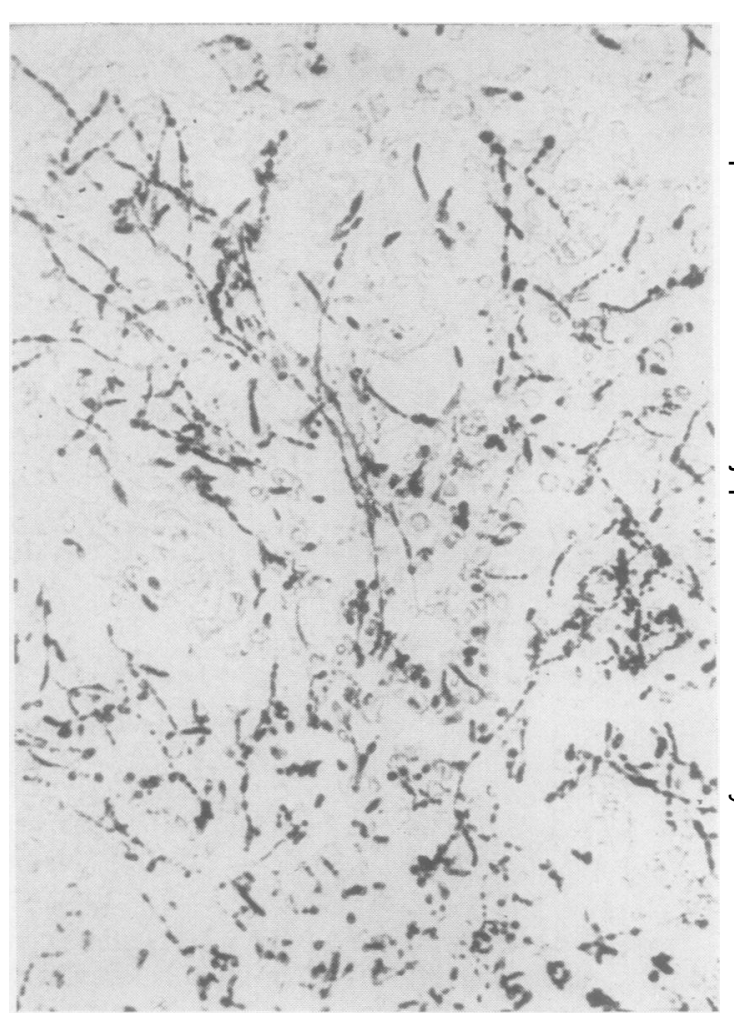

FIG. 2. Masses of Candida in alveolar exudate. Gram $\times 525$.
FIG. 3. Alveolar leucocytic exudate containing a multinucleated giant cell.

Haematoxylin-eosin. $\times 455$.

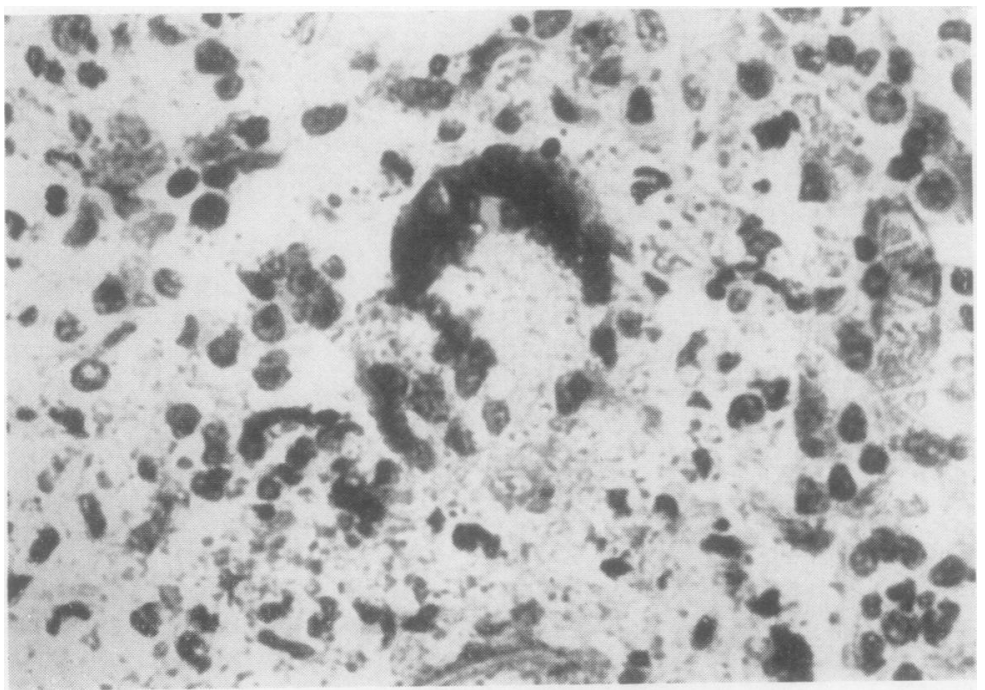




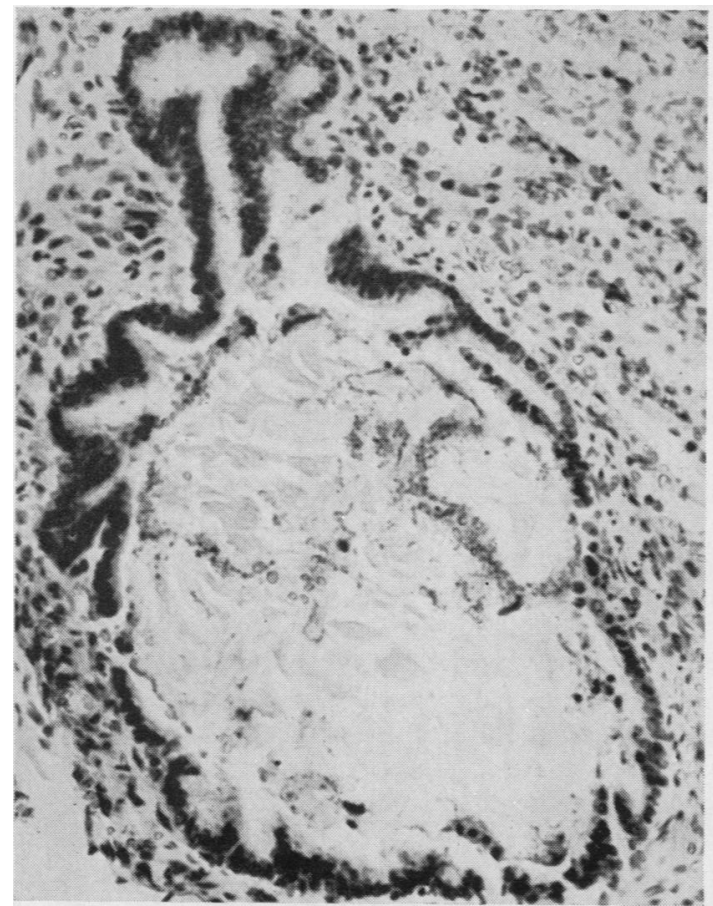

FIG. 4. Bronchi filled with aspirated vegetable matter. $A$ rim of Candida surrounds a particle in the middle right field. Haematoxylin-eosin. $\times 128$.

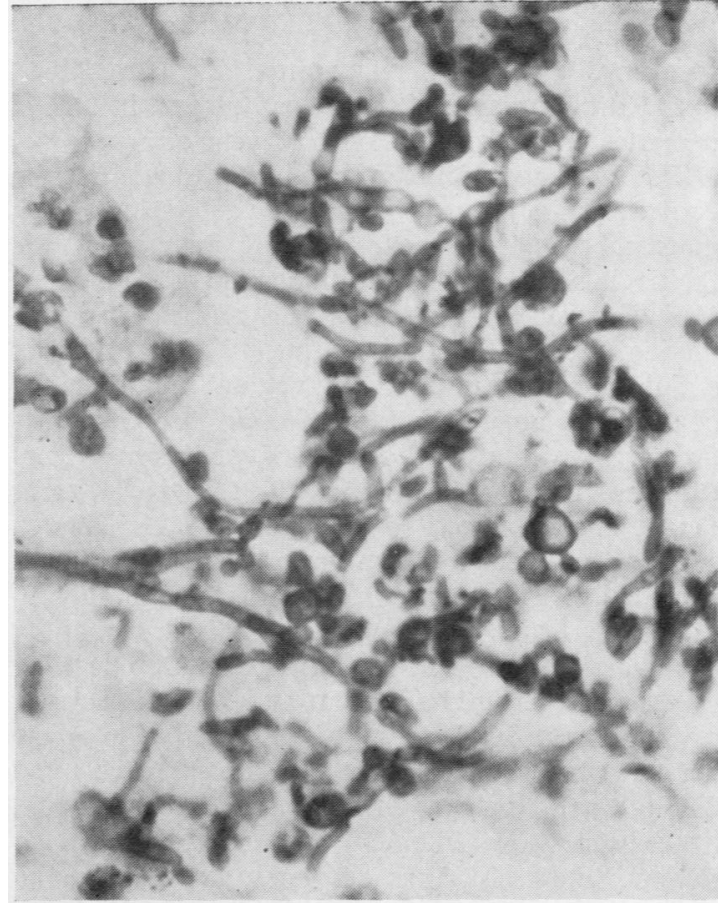

FIG. 6. High-power view of the mycotic flora in an alveolus showing blastospores and pseudomycelia. The septate character of the fungi is evident. P.A.S. $\times 1,152$.

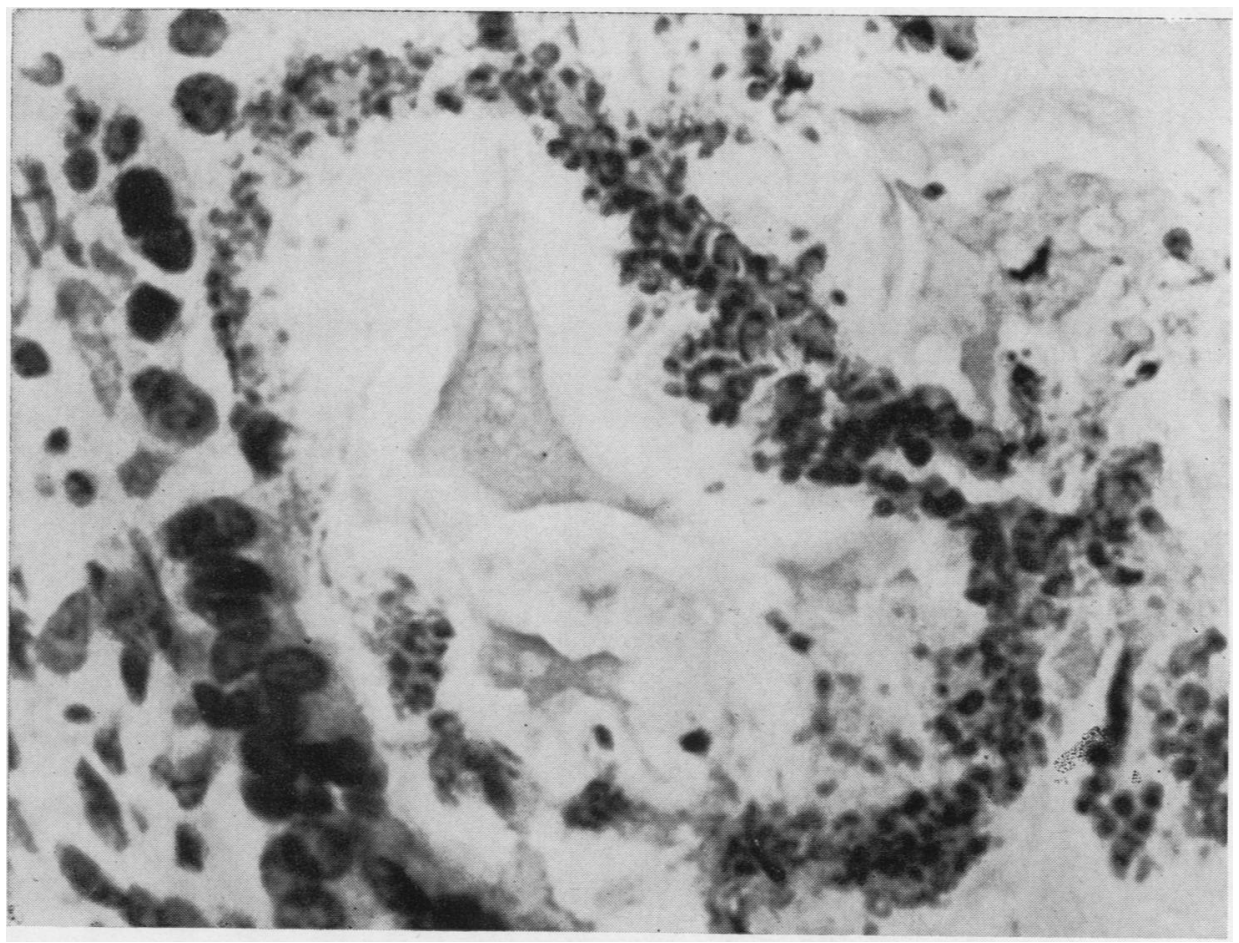

FIG. 5. Detail

of Fig. 4

showing

blastospores

around $a$

particle.

Haematoxylin-

eosin. $\times 616$. 
where associated with inflammation is, properly speaking, aspiration pneumonia. Epstein (1924) found oral thrush in $2.4 \%$ neonates and in $24.6 \%$ neonates and infants 6 days to 1 year of age.

The exogenous source of aspirated Candida is the controversial point. Generally, aspiration from maternal vaginal infection during passage of the foetus has been greatly emphasized (see Dobias, 1957 , for review). Studies on this problem are conflicting. Woodruff and Hesseltine (1938) state that in a child born of a mother with vaginal moniliasis the chances of acquiring the infection are 35 times greater than in a child of a healthy mother. Others (Stastná, Drexler, and Hnátek, 1956) give a lower figure, and some writers (Ludlam and Henderson, 1942) go so far as to claim that maternal vaginitis is practically without importance for the infant. Undoubtedly bronchopulmonary moniliasis secondary to vaginal infection in the mother may be possible but the results in the present series do not suggest a vaginal source of infection. All except one of the neonates were 4 days or older. If infection is acquired during birth, it seems likely that moniliasis would have been more frequently observed in younger infants. In one instance delivery was by caesarean section, thus excluding the likelihood of vaginal contamination. In case 9 the twin brother died two days after birth from hyaline membranes and suffocation, without evidence of Candida. In cases 3, 4, and 6 the fungi were in definite association with aspirated food particles. In cases 1, 2, and 10 the possibility of vaginal infection cannot be entirely dismissed, although definite evidence for or against is lacking.

In view of the ubiquitous nature of $C$. albicans the sources of infection are many. Clothes, bed sheets, and rubber teats, to mention but a few objects, are potential sources of fungi. Stowens (1959) also mentions the danger of infection from the nipples of the mother.

In three instances monilia were clearly disseminated from the mouth to the pharynx and larynx. In the remaining cases it is conceivable that a primary lesion in the mouth or pharynx was so small as to have been missed at necropsy. References to this possibility have been reported in the literature (Ludlam and Henderson, 1942; Vorreith, 1953).

The occurrence of Candida in the bronchi without evoking an inflammatory reaction appears to point to the very early stages where, although the pathogenic organisms are present, proper conditions in the host are lacking for full expression of virulence. An inflammatory reaction to Candida in the oral mucosa, for example, is generally slight. To reason by analogy, lesions elsewhere might very well begin with extremely minimal exudation or none at all. Furthermore, it is highly probable that the period of latency is often related to the administration of antibiotics.

The presence of bacteria together with Candida raises the question as to whether the former and not the latter was the aetiological agent of the pneumonia. The sheer massiveness of Candida compared with the bacterial flora seems to make this possibility unlikely. Moreover, Candida was always found close to the foci of severest inflammation.

Provided that sections are properly stained there is little difficulty in identifying the fungi. Ordinary haematoxylin-eosin stains Candida, but it is not recommended for unequivocal identification as the blastospores can often be mistaken for disintegrated nuclear fragments of leucocytes or vice versa. In two instances where a presumptive diagnosis of monilial pneumonia was considered at necropsy, bronchial swabs failed to produce growths. Equally surprising is the fact that in other cases of positive cultures (not included in the present report) no organisms were found histologically. Aside from the possibility that this may represent accidental contamination, no explanation can be offered at the present time.

We wish to express our gratitude to Professor Josef Vaněk, Director, Sikl Institute of Pathological Anatomy, for his advice in the course of the study and his helpful criticisms of the manuscript.

\section{REFERENCES}

Birch-Hirschfeld, - (1875). Jber. Ges. Natur.-u. Heilk. Dresden. p. 26. Cited by Dobias.

Dobias, B. (1957). A.M.A. J. Dis. Child., 94, 234.

Epstein, B. (1924). Jb. Kinderheilk., 104, 129.

Hall, M. J. (1960). Amer. J. clin. Path., 34, 313.

Hottinger, A. (1956). Ann. paediat., 187, 218.

Ludlam, G. B., and Henderson, J. L. (1942). Lancet, 1, 64.

Nézelof, C., and Sarraut, S. (1957). Sem. Hôp., Paris, 33, 1.

Štastná, J., Drexler, S., and Hnátek, J. (1956). Cs. Pediat., 11, 512.

Stowens, D. (1959). Pediatric Pathology, p. 252. Williams and Wilkins, Baltimore.

Vorreith, M. (1953). Cas. Lék. čes., 92, 455.

Woodruff, P. W., and Hesseltine, H. C. (1938). Amer. J. Obstet. Gynec., 36, 467. 